\title{
Can Hepatitis B Mothers Account for the Number of Missing Women? Evidence from Three Million Newborns in Taiwan
}

\author{
Ming-Jen Lin and Ming-Ching Luoh *
}

\begin{abstract}
The 'missing women' phenomenon in many Asian countries has previously been regarded as the result of son preference and change in economic conditions. However, some studies later argued that since the sex ratio of the offspring of Hepatitis B mothers is around 150, half of the missing women can be explained by this natural disease.

Using an atypical national data set from Taiwan, we demonstrate that the marginal probability of an $\mathrm{HBs} \mathrm{Ag}(+)$ mother having a male birth ranges only from 0.0010 to 0.0025 . In addition, this estimate does not vary with birth order and the sex composition of previous children. Given that 15 percent of mothers are HBV carriers, the disease can only raise the sex ratio from a base line of 105 to 105.165 at most. Our estimates suggest that the effect of HBV mothers on the offspring sex ratio, and hence on the cause of missing women, is minimal. Finally, we find that a third or higher birth, particularly in families where the first two children are female, the probability that the third child is male rises by 0.02, from a baseline sex ratio of 105 to 115 .
\end{abstract}

\footnotetext{
Ming-Jen Lin and Ming-Ching Luoh are, respectively, Associate Professor and Professor at the Department of Economics, National Taiwan University; the corresponding author is Ming-Jen Lin. Address for correspondence: Department of Economics, National Taiwan University, No.21 Hsu Chow Road, Taipei 100, Taiwan. Tel: 886-2-23519641ext 463, email: mjlin@ntu.edu.tw.
} 


\section{INTRODUCTION}

In an article entitled 'More than 100 million women are missing', Sen (1990) argued that if men and women were treated equally, the number of women should be greater than the number of men because women are 'hardier' (referring to the tendency they live longer). However, in some Asian societies, discrimination against women ${ }^{1}$ has resulted in the survival of much fewer female than would otherwise be expected. ${ }^{2}$ This missing women phenomenon has received much public attention because of its profound humane and social implications. ${ }^{3}$

The amount of missing women can be measured by calculating the difference between the number of women that 'should be' alive and the number that 'actually are' alive. Sen (1990) calculated that in China alone there were 49.98 million 'missing women'. This figure rose to 100 million when India, Pakistan and other Asian countries were included. ${ }^{4}$ Most people believe that this 'missing women' phenomenon is due to son preference. In addition, many studies (Edlund 1999, Foster and Rosenzweig 2001, and Qian 2006) showed that economic factors can also alter sex ratio. ${ }^{5}$

However, if the high sex ratio is at least partially attributable to some natural causes

\footnotetext{
1 The practices include infanticide, or providing fewer resources for newborn females. These cases are usually not reported as live births. Parents may also neglect a daughter's educational or nutritional needs later in life as well. However, Coale and Banister (1994) argued this discrimination mainly occurred during the early stages.

2 The situation for women deteriorated further starting in the late 1970s' because of sex selection technology and government policy. For example, amniocentesis techniques were developed in India in 1975, and soon became a popular practice for sex selection. China launched its 'one-child' policy in 1979, while ultrasound became popular in the late 1980s. As a result, the sex ratio at birth rose from 107.1 in 1981 to 116.9 in 2000.

3 For example, it can generate disturbances in future marriage market, and even causes international security problem (Hudson and de Boer, 2004).

4 Using a diverse range of comparison criteria, Coale (1991) and Klasen (1994) modified this loss down to around 60 million. Klasen and Wink (2002) used more recent data and argued that the situation has improved in most countries, but has gotten worse in China and India.

Basically, parents raise more sons if the rate of return to invest daughters is lower than that of sons (Becker 1981). For Example, Qian (2006) and Olds (2006) showed the increasing value of female labor due to the rise of tea trade would increase the survival of female infants.
} 
rather than cultural and economic factors, then this should be excluded when calculating the number of missing women. One natural cause that has been widely discussed recently is the Hepatitis B virus (HBV). The pioneering micro-level studies of Blumberg ${ }^{6}$ and his coauthors argue that a mother who was infected with the HBV was 1.5 times more likely to give birth to a male. Oster (2005) subsequently estimated that as much as half of the 'missing women', and up to 75 percent of those in China could be explained by HBV.

In response to this novel biological explanation, Das Gupta $(2005,2006)$ has pointed out that in China, the sex ratio at birth for the first birth was always in the normal range of 1.05 to 1.06 , and that the abnormally high sex ratio observed at birth came basically from higher birth orders. In addition, the higher sex ratio at birth was only found among women who have only daughters. These facts strongly suggest that missing women are due to son preference. However, Oster (2006) replied that one can not rule out the biological explanation simply because he or she finds support for a cultural explanation. Furthermore, HBV may still interact with birth order and sex composition of previous children in complicated ways, or it may simply be that the probability a woman has HBV raises with the number of children she bears, thus causing later births to present an atypical sex ratio. These two HBV hypotheses may still be consistent with the above China's sex ratio pattern.

To test these alternative theories, we explore a very atypical and comprehensive data set: a total of three million births from the Hepatitis B Mass Immunization (HBMI) national databank of Taiwan. Our data includes gender, year and month of birth, birth place, mother's age, birth order of the child, unique ID of the mother, and the HBV status at the time of a mother's pregnancy. To the best of our knowledge, it is the first time in the

\footnotetext{
6 Dr Blumberg's research on the identification of the Hepatitis B virus was honored by the 1976 Nobel Prize of medical science.
} 
literature that both the biological (HBV status) and cultural (birth order) factors were analyzed at the same time.

To perform a definitive analysis to sort out whether missing women are due to son preference or $\mathrm{HBV}$, we address the following questions in order: What is the impact of HBV infection on the overall sex ratio at birth? How does this impact vary with birth order? How does the impact of HBV status differ by whether one's first two children are both girls? The answer to the first question will help to evaluate the basic premise of the HBV calculation. And the latter two questions test whether HBV interacts with birth order and sex composition of previous children in a complex biological way that produces the particular sex ratio pattern observed in China.

We first briefly describe our findings here. For the first question, we found that the impact of HBV infection on the overall sex ratio at birth is very small, and are not always significant. The marginal effect of HBV on the probability of a male birth is between 0.001 and 0.0025 . With a 15 percent HBV infection rate among mothers in Taiwan, ${ }^{7}$ the figure can raise Taiwan's sex ratio to 105.165 at most. ${ }^{8}$ Correspondingly, this marginal effect can only explain about $0.9 \%$ to $1.8 \%$ of the missing women in China. Furthermore, a large part of the sex ratio variation of Taiwan comes directly from higher birth order, evidence that is consistent with the son preference hypothesis.

For the second question, we found that coefficients of the interaction effects between a mother's HBV status and a child's birth order were insignificant and very small. Also, the HBV effect on the sex of the offspring does not vary when sample was separated by

\footnotetext{
7 Oster (2005) estimated that China's HBV prevalence rate was $13.61 \%$; the HBV carrier rate by mothers in Taiwan is about $16.4 \%$ in our data.

8 For the normal sex ratio 105 , the probability of having a male child is $0.512195(0.512195 /(1-0.512195)$ $=105)$. Given that the marginal probably of HBV is 0.0025 and 15 percent of all mothers are infected, the sex ratio of the whole population would be $(0.512195 \times 0.85)+(0.514695 \times 0.15)=0.51257$, or 105.16 . If an HBV mother is 1.5 times more likely $(0.6 / 0.4)$ to have a male birth, then the estimate would need to be $0.088(0.6-0.512)$, which is 35 times greater than the figure obtained in this study.
} 
birth order either. Finally, we also found that for the third birth, the coefficient of the interaction effect between HBV and a dummy variable representing whether or not the first two children were girls was again insignificant and very small. These small and insignificant interaction effects rule out the hypothesis that HBV interacts with birth order or sex composition of previous children in a complex way that raises the sex ratio at higher birth. In addition, probability of being a male infant for the third birth increases dramatically when his first two siblings were both girls. Along with a very small HBV effect found in all model specifications, our evidence supports the son preference rather than the HBV story.

The rest of this paper is organized as follows: Section 2 provides the literature review. Section 3 describes the data set in detail. Section 4 estimates the impact of HBV and its interaction with birth order and sex composition of previous children. Section 5 concludes.

\section{LITERATURE REVIEW}

$\mathrm{HBV}$ is an enveloped DNA virus which is transmitted from a person who is Hepatitis B surface antigen (HBsAg) seropositive and is contracted either through vertical (at birth from the mother) or horizontal (iatrogenic or sexual) channels (Murray et al., 2005). Using micro-data from all around the world, Blumberg and his coauthors ${ }^{9}$ have reported higher sex ratios (about 1.5) for $\mathrm{HBV}(+)$ women than those reported for HBV(-) women.

As pointed out by Oster (2005), data obtained on individuals is the most straightforward way of testing the HBV hypothesis; however, the prior micro studies have suffered from several inherent drawbacks. These include small numbers of observations, the poor quality of the data used (Chahnazarian et al. 1988), samples being obtained from

\footnotetext{
9 See, for example, Hesser et al. (1975), Cazal et al. (1976), Livadas et al. (1979), Drew et al. (1978; 1982; 1986) and Chahnazarian et al. (1988).
} 
limited locations, and some samples having extremely high or low sex ratios of either HBV or non-HBV women.

There are also questions raised with regard to sample selection, underreporting, the fact that the seropositive test is retrospective, ${ }^{10}$ and the fact that some of the supporting studies were not originally designed to test the HBV hypothesis at all. Finally, the exact biological mechanisms of this hypothesis remain unknown. Although Drew, Blumberg, et al (1978) hypothesized that HBV positive women were more likely to 'spontaneously abort' a female fetus, Livadas et al. (1979) were unable to find any statistical evidence to support such a proposition.

Nevertheless, inspired by previous micro level work, Oster (2005) went on to present wide-ranging evidence arguing that HBV had a positive correlation with sex ratio at birth. The evidence included the high sex ratio at birth found within historical Chinese data (average 109.5), ${ }^{11}$ the high sex ratios of Chinese immigrants' children who had been born in the US (average 111.5), differences-in-differences estimations derived from two natural experiments based upon recent vaccination campaigns (Taiwan and Alaska), ${ }^{12}$ and cross-country evidence. All of this evidence support for the hypothesis that HBV carriers were 1.5 times more likely to have a male child.

The HBV hypothesis, if correct, would account for roughly half of the previous ‘missing women' (Oster 2005). In response, Das Gupta $(2005,2006)$ reported that in China the sex ratio at birth was in the normal range of 1.05 to 1.06 for first births, and it became abnormally high(i.e., more males) at higher birth orders (Zeng et al. 1993). ${ }^{13}$ Data

\footnotetext{
10 That is, they only knew of the women's HBV status at the time of the survey, not at the time of their pregnancy.

11 This historical Chinese data was taken from Coale and Banister (1994), Table 3.

12 The idea was that these natural experiments provided diverse environments in which to compare the differences in the sex ratios between a aboriginal (high HBV-infection group) vis-à-vis a non-native (low $\mathrm{HBV}$-infection group) before and after the vaccination program.

13 See Park and Cho (1995) for similar results in S. Korea. Das Gupta (1987), Choe (1987), and Muhuri
} 
on the sex ratio at birth in China in Table 1 corroborate this argument. In addition, Das Gupta (2006) also argued the higher sex ratio for later births was strongly correlated with the sex composition of the existing child(ren) of the family. ${ }^{14}$ Furthermore, Das Gupta and Li (1999) showed that in China, India and Korea, sex ratio responded closely to political and other events during the 20th century. In addition, Qian (2006) found that the variation in the enforcement of the One Child Policy explain as much as 10 percentage points in female survival.

$<$ Table 1 is inserted about here $>$

Das Gupta (2006) considered the above evidence to be consistent with the son preference hypothesis. She further argued that in order for the HBV theories to be consistent with the particular sex ratio pattern in China, "women would have to be especially prone to contracting HBV if they had borne a daughter, or HBV somehow leads to women first bearing daughters, followed by an excess of sons, and either of these outcomes required a much more complex biological mechanism." She concluded that it was extremely difficult, if not impossible, to reconcile this HBV hypothesis with such data.

In response to these comments, Oster (2006) argued that "Das Gupta's conclusion that support for a cultural explanation largely rules out the biological explanation - is flawed." She argued that two different countries could have diverse levels of sex ratios at birth, but that economic and cultural factors within these countries could still move the ratios around, so that it would be better to view these two theories as being “complementary".

and Preston (1991) also found that the sex differentials in child mortality depends heavily on the birth order of the child in India, S. Korea, and Bangladesh.

14 For example, if the first child was a girl, then the sex ratio of the second child would increase to 1.494, as opposed to a ratio of 1.014 if the first child was a son. 
Besides, the particular sex ratio pattern of China, that is, abnormal imbalance sex ratio in higher birth orders only, may still be consistent with the HBV hypothesis. We consider two alternative hypotheses here. First, HBV may interact with birth order or sex composition of previous children through some 'complex biological mechanism' that raises the sex ratio of higher birth orders. Second, it is likely that the percentages of HBV positive mothers are much higher in the higher birth order data points than in the first and second birth cases.

Thus, the literature is in an ongoing debate between the two competing hypotheses: cultural (son preference, or economic) vs. biological (HBV). However, evidence provided from either side cannot thus far exclude the possibility of the other because neither investigates $\mathrm{HBV}$ and parity at the same time. One way to disentangle the explanatory power of both theories is to investigate directly the effect of $\mathrm{HBV}$ on sex ratios and simultaneously see if this effect differs by birth orders or sex composition of previous children. If the HBV effect is small and does not vary with birth orders or sex composition of previous children, then both hypotheses of HBV causality mentioned above are not supported. The strong influence of birth orders and sex composition of the previous children on sex ratio could then also be used as evidence supporting the son preference story. An ideal dataset for this purpose would be comprised of micro-data containing birth order of the children, information on the HBV status of the mother at pregnancy, the gender of the child, and a large number of observations. We now go on to present such a dataset.

\section{DATA SOURCE}

Historically, the HBV rate in Taiwan has remained at around 15 percent to 20 percent (Chen and Sung, 1977) and has, therefore, consistently been high on the list of public 
health concerns. To reduce the infectivity and risk of $\mathrm{HBV}$, a mass immunization program was launched in Taiwan in 1984 for all infants born to $\operatorname{HBsAg}(+)$ mothers, the first program of its kind in the world. By 1986, all newborn babies in Taiwan were receiving the Hepatitis B vaccine. Infants born to $\mathrm{HBsAg}(+)$ mothers are also given an additional Hepatitis B immune globulin within 24 hours of birth, which explains why every pregnant woman in Taiwan is required to be tested for HBsAg.

The Hepatitis B Mass Immunization (HBMI) databank maintained by the Center for Disease Control (CDC) in Taiwan keeps detailed records of the mothers and infants that received immunization in the program for future academic and policy purpose. It includes gender, year and month of the child's birth, the age of the mother (at the birth of the child) and the birth place (township). The databank also includes the mother's ID, a unique number that can be used to associate all the children born to the same mother, and most important of all, the HBsAg status at the time of her pregnancy. Children born to the same mother are sorted by their date of birth in order to identify their birth order. ${ }^{15}$ Our sample period is from 1988 to 1999 , during which time over 90 percent of all newborns in Taiwan were immunized. ${ }^{16}$ Note here that CDC did not provide us 1984 to 1987 data because it contains a lot of missing data.

During the introduction of the data, it was noted that the birth orders used in our analysis were imputed by sorting the birth dates of children born to the same mother. This will systematically underestimate the birth order, because a child who was identified as being the first child born to a mother may actually have been her second or third child, particularly in the case of the samples covering the earlier years. Hence the sex ratio for

\footnotetext{
15 That is, one's real birth order can never be less than his or her imputed birth order.

16 The CDC designed a special process to coordinate agencies within local hospitals, and within the local government population and health sector. All of the data was sent back to the CDC for final checking and coding. All pregnant women and their babies now receive a yellow 'immunity record' card; without this immunity record, the child would be unable to attend elementary school.
} 
first and second birth reported in may be overestimated. In order to mitigate the potential bias, we will report results from three different groups throughout the whole paper: those mothers who were aged 25 or below when they first appeared within the dataset, those mothers who were aged 25 or below in year of 1988, and the full sample results. However, as readers will see in later analysis, all the coefficients estimated do not vary with the range of the sample selected.

Table 2 summarizes the sex ratio at birth, by order of the first, second and third (or subsequent) births, as well as HBsAg status for the entire study period of 1988-1999, for those mothers who were aged 25 or below when they first appeared within the dataset. This restriction will result in dropping all of those women whose "alleged" first birth occurred after the age of 25 . The summary statistics show three empirical regularities: first, the abnormal sex ratio appear in the third birth (113.4 to 114.6), while the sex ratio for the first two births are within the normal range (105.9 to 107.2); second, between HBsAg positive and negative mothers, the difference in offspring sex ratio for the first, second, and third births are $0.00238,0.0015$, and 0.0025 ; finally, the HBsAg prevalence rate is roughly $17 \%$ and stable across birth order, indicating that $\mathrm{HBsAg}$ is not correlated with birth order. The regression analysis that follows will also provide evidence consistent with these findings. Also the full sample summary statistics presented in the appendix provide the same pattern. Finally, we also calculate sex ratio and HBV infection rate by county (not reported at table 2), and find that while sex ratios vary widely from across counties, HBV infection rates do not (around $15 \%$ to $17 \%$ ).

$<$ Table 2 is inserted about here $>$ 


\section{EMPRICAL RESULTS}

In order to further investigate the relationship between $\mathrm{HBsAg}$ and the probability of having a male birth, we run the following full specification:

$$
\begin{aligned}
\text { Boy }_{i}= & \alpha_{i}+\beta 1 \text { HBsAg }+\beta 2 \text { Birth Order } 2_{i}+\beta 3 \text { Birth Order } 3 \text { and above }{ }_{i} \\
& +\beta 4 \text { HBsAg *Birth Order } 2_{i}+\beta 5 \text { HBsAg* Birth Order } 3 \text { and above }_{i} \\
& +\beta 6 * \text { Mother Age Dummies }+\beta 7 \text { Child Birth Year Dummies } \\
& +\beta 8 * \text { Birth Township Dummies }+\varepsilon_{i}
\end{aligned}
$$

where the dependent variable is Boy $=1$ (otherwise 0 ); HBsAg is either positive $(=1)$ or negative $(=0)$; mother's age dummies are included for each year (15-49); child birth year dummies are from 1988-1999; and $\alpha_{i}$ is the constant term.

Here, $\beta 1$, the effect of HBsAg on sex ratio, is our major interest. Positive $\beta 2$ and $\beta 3$ values indicate the offspring in later higher birth orders are more likely to be male, a measure of the degree of son preference. $\beta 4$ and $\beta 5$ investigate whether the impact of HBsAg behaves differently among different birth orders. If $\beta 4$ and $\beta 5$ are small and insignificant, then it is clear that birth orders do not amplify the effect of HBsAg. That is, the HBV impact is independent of and does not vary with birth order. This allows us to rule out the 'complex biological mechanisms' story. In this case, $\beta 1$ alone would be the final judgment on the HBV impact.

The probit estimation ${ }^{17}$ results are presented in Table 3 . We report marginal effect, coefficient estimates, and the robust standard errors respectively. The first five columns use mothers who were aged 25 or below when they first appeared in the dataset as our sample. The coefficient in column (1) represents the result where HBsAg is the only

\footnotetext{
17 OLS can also provide useful information since our main interest is the marginal effect. Please see the appendix for the corresponding tables. Essentially both methods yield identical results.
} 
regressor. The marginal probability, 0.0023 , is $95 \%$ significant but small. As we gradually add in the controls, such as birth orders, mother's age (15-49) dummies, birth year and township dummies (columns 2 to 4 ), the estimate remains around 0.0022 to 0.0023 . In column (5), we add in interaction between $\mathrm{HBsAg}$ and birth orders. The marginal probability of the HBV effect for the first birth $(\beta 1)$ is 0.0027 , but become insignificant. The final column further reduces our sample to those mothers who were aged 25 or below "in the year 1988" and uses full model specification. Again $\beta 1$ becomes smaller (0.00096) and again is not significant. Furthermore, estimates of $\beta 4$ and $\beta 5$ in column (5) and (6) are all insignificant and small in all specifications. ${ }^{18}$ In table 4, probit estimation using the full 3 million samples shows the same result: the impact of HBV is around 0.0022 to 0.0024 . However, the coefficients are all significant, probably due to the large size of the sample. The interaction effect between HBsAg and birth orders are still small and insignificant. Table 3 and 4 indicate that the effect of HBsAg on sex ratio is quite small, and sometimes insignificant. More importantly, this effect does not vary with birth order. This shows that HBV does not have any special effect on the sex ratio of higher birth orders. In other words, the HBV virus cannot recognize birth order. Furthermore, the marginal probability of second birth $\left(\beta_{2}\right)$ is small, insignificant, and without a clear sign. But the marginal probability of third or higher birth, $\beta 3$, which range from 0.011 to 0.027 , is significant at $99 \%$ level and very large. Obviously, the variation in the sex ratio comes from third and higher birth order in our data.

$<$ Table 3 is inserted about here $>$

$<$ Table 4 is inserted about here $>$

One might argue that specification of equation (1) can only prove that the interaction $18 \beta 1, \beta 4$, and $\beta 5$ are not jointly significant either. 
effect between HBsAg and birth orders toward sex ratio is not linear. We hence further run the full specification of Equation (1), but restrict our sample to each birth order. We present results from three different sample selection criteria in Table 5. Again, the impact of $\mathrm{HBV}$ is small, and only 2 out of the 9 columns (both using the full sample) are significant. Furthermore, this HBV effect does not vary with birth order.

$<$ Table 5 is inserted about here $>$

Finally, since we can identify birth order and sex of each child within family, we can also estimate whether the impact of HBV varies with the sex composition of previous children, and how this composition affects the sex ratio of later children. We run:

$$
\begin{aligned}
\text { Boy }_{i}=\alpha_{i}+ & \beta 1 \text { HBsAg }+\beta 2 \text { First two children are girls }+\beta 3 \text { HBsAg* First two children } \\
& \text { are girls }+\beta 4 * \text { Mother Age Dummies }+\beta 5 \text { Child Birth Year Dummies } \\
& +\beta 6^{*} \text { Birth Township Dummies }+\varepsilon_{i}
\end{aligned}
$$

Notice that the sample here is only for the third birth. ${ }^{19}$ Table 6 shows that the HBV impact is insignificant, extremely small (around -0.002 to -0.0001 ), and even negative. $\beta 3$, the interaction effect between HBsAg and mothers who have two girls already, is also insignificant and very small (around 0.003 to 0.006 ). This shows that the HBV effect is minimal and does not interact with the sex composition of the first two children, and hence refutes the complex biological mechanism story. Finally, we find that if the first two children are both girls, the probability that the third birth is male would be increased by $0.023(\beta 2)$, or from a baseline of 105 to 115 . This is again strong evidence consistent with the son preference story.

\footnotetext{
19 Table 2, 3, and 4 all show that the sex ratio at birth among first and $2^{\text {nd }}$ birth is indifferent. This indicates that parents with son preference start to seek for help from technology after the first two tries fail. Hence it is reasonable to focus our attention on the higher birth only.
} 
$<$ Table 6 is inserted about here $>$

So far our results have indicated that the marginal effect of HBV on the probability of having a male child is small, only significant when the full sample is used, and sometimes even negative. Also, this HBV impact varies neither with birth orders nor with the sex composition of first two children. One may conclude that HBV does not have any effect on sex ratio at birth. Even if we take the largest estimate of marginal probability, which is only about 0.0025 in all of our regressions, HBV cam only raise the sex ratio at birth from the baseline of 105 to $105.16^{20}$ Using this number, we now can provide an upper bound 'back of the envelop' calculation on the ultimate economic question: how many percentage of missing women can be explained by HBV? Sen (1990) calculated that the number of missing women in China is equal to (1.066(actual sex ratio)-0.977(expected sex ratio)) $\times$ 548.7 (number of total female) $\div 0.977=49.98$ million. Assuming that the mortality rate is the same, then the actual number of missing women would be $(1.066-0.9785) \times 548.7 \div$ $0.9785^{21}=49.066$ million. In other words, even though we use the highest number we estimated, HBV mother can explain about $1.8 \%$ of the missing women at most. ${ }^{22}$

There is, however, one caveat with regard to our research methodology which needs to be addressed here. During our data period (1988-1999), sex-selective abortion had already become a popular practice. The concern is that if sex-selective abortion is correlated with HBV, then we will not be able to disentangle the biological effect of HBV from the volitional effect of preference. If HBV positive mothers are more likely to abort girls, then the results overestimate the true effect of HBV on having a boy. On the other hand if HBV positive mothers are less likely to abort, then the results underestimate the

\footnotetext{
20 given that the prevalence rate of $\mathrm{HBV}$ is roughly $15 \%$ in China.

$21 \quad 0.9875=0.977+0.0016 * 0.977 / 1.05$

22 If we assume that $100 \%$ of China's population is HBV positive, then 0.0025 would roughly account for $25 \%$ of the missing women in China.
} 
true effect of HBV on having a boy. The latter would be consistent with a model where positive and negative mothers have the same demand for boys. And the negative mothers, who may be less likely to have boys, "make up" for this by aborting more.

However, we consider this scenario unlikely or unimportant for three reasons. First, if HBV(-) mothers were really aborting more children, we should observe the gap in sex ratios between children of positive and negative mothers narrow over birth years as sex selective abortion become more accessible. Instead, this gap remained stable around 0.0010 to 0.0025 from 1988 to 1999 , and does not show any particular tendency to convergence. Furthermore, the fact that the interaction between HBV and birth order or sex composition of previous children are small and insignificant also indicates that HBV positive and negative mothers have the same pattern about their fertility behavior. Finally, even if we allow this argument all reasonable doubt ${ }^{23}$, the upper bound of the HBV effect still should not exceed 0.004 since the sex ratio of the first birth to an $\mathrm{HBV}(+)$ mother is only 106.9 from Table 2 .

Furthermore, in response to the working paper version of this paper, Bloomberg and Oster (2007) proposed that both Oster (2005) and our results can be right if it is the paternal rather than the maternal infection that is in effect. Following the discussion above, it is likely that the father's HBV status is the key factor on determining sex ratio if fathers of the third (or higher) birth have much higher HBV infection rate, or fathers are 'especially prone to contracting HBV if they had borne a daughter, or HBV somehow leads to fathers first having daughters, followed by an excess of sons (rephrasing Das Gupta 2006).' Again in order to separate the two competing hypothesis, one need a large scale micro data set that consists of the father's and mother's HBV status, and the birth

\footnotetext{
23 That is, all of the increment from the normal sex ratio, 105, for $\mathrm{HBV}(+)$ mothers stems from $\mathrm{HBV}$.
} 
parity of their children. Unfortunately, we cannot find such a data set now, but this would be an interesting research direction in the future.

\section{CONCLUSION}

The ‘missing women' phenomenon in many Asian countries has previously been regarded as the result of strong son preference (Sen 1990). However, the HBV hypothesis claims that mothers with HBV are 1.5 times more likely to have a male child. As a consequence, half of the 'missing women' (75\% in China) could be attributed to this biological factor (Oster 2005).

In response, Das Gupta $(2005,2006)$ pointed out that in China, the imbalance in sex ratio at birth largely comes from a mother's third or higher birth, or from those women who have borne only daughters. These two stylized facts which are often viewed as evidence in support of the son preference hypothesis. Hence one should control for birth order (which previous HBV literature did not) when estimating of the HBV effect.

However, the HBV hypothesis may still be consistent with the particular stylized fact mentioned above if mothers of the third (or higher) birth have a much higher HBV infection rate than those of first and second births. It is also likely that women are "especially prone to contracting HBV if they had borne a daughter, or HBV somehow leads to women first bearing daughters, followed by an excess of sons" (Das Gupta 2006). Although these outcomes required a much more 'complex biological mechanism', data with parity but not HBV information cannot rule them out either.

This paper contributes to this debate by investigating a national dataset from Taiwan which contains parity and HBsAg status of the mother at the same time. We find that the marginal effect of a HBsAg mother on the probability of having a male birth is only 0.0025 at most. Furthermore, this estimate does not vary with birth order or sex 
composition of previous children. This indicates that HBV positive and negative mothers exhibit the same pattern in the sex ratio of their children, and rules out the possibility of the complex biological mechanism story mentioned earlier. As a consequence, HBV positive mothers can only account for $1.8 \%$ of the number of missing women. Finally, the higher total sex ratio at birth is mainly driven by the higher birth order children and mothers who have only girls, evidence that is consistent with the son preference hypothesis. 


\section{REFERENCES}

Becker, G. (1981), a Treatise on the Family, Cambridge, MA: Harvard University Press.

Blumberg, B. and E. Oster (2007), 'Hepatitis B and Sex Ratios at Birth: Fathers or Mothers?' Working Paper, the University of Chcago.

Cazal, P., J.M. Lemiare and M.R. Levy (1976), 'Hepatitis B et Rapport du Masculinite', Revue franaise de transfusion et immunohmatologie, 19:577-81.

Chahnazarian, A., B.S. Blumberg and W.T. London (1988), 'Hepatitis and the Sex Ratio at Birth: A Comparative Analysis of Four Populations', Journal of Biosocial Science, 20(3): 357-70.

Chen, D.S. and J.L. Sung (1977), 'Hepatitis B Virus Infection on Taiwan', New England Journal of Medicine, 297(22), (September): 668-9.

Choe, M.K (1987) 'Sex differentials in infant and child mortality in Korea', Social Biology, 34:12-25.

Coale, A.J (1991), 'Excess Female Mortality and the Balance of the Sexes in the Population: An Estimate of the Number of Missing Females', Population and Development Review, 17(3): 517-23.

Coale, A.J. and J. Banister (1994), 'Five Decades of Missing Females in China', Demography, 31(3): 459-79.

Das Gupta, M. (1987) 'Selective discrimination against female children in rural Punjab, India', Population and Development Review, 13(1):77-100.

Das Gupta, M. (2005), 'Explaining Asia's Missing Women: A New look at the Data', Population and Development Review, 31(3): 529-35.

Das Gupta, M. (2006), 'Cultural versus Biological Factors in Explaining Asia's "Missing Women”: Response to Oster' Population and Development Review, 32(2): 328-32.

Das Gupta, M. and S. Li (1999), 'Gender bias in China, South Korea and India 1920-1990: 
the effects of war, famine and fertility decline'? Development and Change, 30(3):619-52.

Drew, J., W.T. London, E. Lustbader, J.E Hesser and B.S. Blumberg (1978), 'Hepatitis B Virus and Sex Ratio of Offspring', Science, 201(25): 687-92.

Drew, J., W.T. London, B.S. Blumberg and S. Serjeantson (1982), 'Hepatitis B Virus and Sex Ratio on Kar Kar Island', Human Biology, 54(1): 123-35.

Drew, J.S., B.S. Blumberg and J.R. Lamblin (1986), 'Hepatitis B Virus and Sex Ratio of Offspring in East Greenland', Human Biology, 58(1): 115-20.

Edlund, L (1999), "Son preference, sex ratios and marriage patters." Journal of Political Economy, 107(6): 1275-1304.

Foster, A and M. Rosenzweig (2001), "Missing Women, the Marriage Market and Economic Growth”, working paper, Brown University.

Gu, B.C. and Y. Xu (1994), 'A Comprehensive Discussion of the Birth Gender Ratio in China', Chinese Journal of Population Science, 6(4): 417-31.

Gu, B.C. and K. Roy (1995), 'Sex Ratio at Birth in China, with Reference to Other Areas in East Asia: What We Know', Asia-Pacific Population Journal, 10(3): 17-42.

Hesser, J.E., J. Economidou and B.S. Blumberg (1975), 'Hepatitis B Surface Antigen (Australia Antigen) in Parents and Sex Ratio of Offspring in a Greek Population', Human Biology, 47(4): 415-25.

Hudson, V. and A. den Boer (2004), Bare Branches: The Security Implications of Asia's Surplus Male Population, Cambridge, MA: MIT Press.

Klasen, S. (1994) 'Missing Women Reconsidered', World Development, 22(7): 1061-71.

Klasen, S, and C. Wink (2002), 'A Turning Point in Gender Bias in Mortality? An Update on the number of Missing Women', 'Population and Development Review', 28(2): 285-312. 
Livadas, D., D.A. Koutras, J. Economidou, J.E. Hesser and S. Hadziyannis (1979), 'Fertility and Sex Ratio of Offspring of Female HBsAg Carriers', Journal of the Royal Society of Medicine, 72(7): 509-12.

Muhuri, P.K., and S.H. Preston (1991) 'Effects of Family Composition on Mortality Differentials by Sex among Children in Matlab, Bangladesh', Population and Development Review, 17(3):415-34.

Murray, P., K. Rosenthal, G. Kobayashi and M. Pfaller (2005), Medical Microbiology, 5th ed, St Louis: Mosby Elsevier.

Olds, K. (2006), 'The Effect of Female Economic Productivity on the Sex Ratio: Evidence from Early-twentieth Century Taiwan', Economics and Human Biology, forthcoming.

Oster, E. (2005), 'Hepatitis B and the Case of the Missing Women', Journal of Political Economy, 113(6): 1163-1216.

Oster, E (2006), 'Explaining Asia's Missing Women: A New Look at the Data Comments', Population and Development Review, 32(2), 323-327.

Park, C. and N. Cho (1995), 'Consequences of Son Preference in a Low-fertility Society: Imbalance of the Sex Ratio at Birth in Korea', Population and Development Review, 21(1): 59-84.

Qian, N. (2006), 'Missing Women and the Price of Tea in China: The Effect of Relative Female Income on Sex Balance', Working Paper, Brown University.

Sen, A. (1990), 'More Than 100 Million Women Are Missing', New York Review of Books, December 20.

Yuan, X. and E.J.C. Tu (2005), 'Analysis of High Sex Ratio at Birth in Mainland China', Journal of Population Studies, 29: 147-81 (in Chinese, with English Abstract).

Zeng Y, P. Tu, B. Gu, Y. Xu, B. Li, and Y. Li,(1993), 'Causes and implications of the recent increase in the reported sex ratio at birth in China', Population and Development Review, 19(2):283-302. 
Table 1 Sex ratio at birth in China, by birth order, 1960-2000

\begin{tabular}{ccccc}
\hline Period Covered & First Child & Second Child & $\begin{array}{c}\text { Third } \\
\text { (or subsequent) } \\
\text { Child }\end{array}$ & Total \\
\hline $1960-1965$ & - & - & - & 107.6 \\
$1966-1970$ & - & - & - & 106.3 \\
$1971-1975$ & - & - & - & 106.3 \\
$1976-1980$ & - & - & - & 106.6 \\
1981 & 105.1 & 106.7 & 111.3 & 107.1 \\
1982 & 106.6 & 105.2 & 109.4 & 107.2 \\
1983 & 107.8 & 107.2 & 109.5 & 107.9 \\
1984 & 102.5 & 113.3 & 113.0 & 108.5 \\
1985 & 106.6 & 115.9 & 114.1 & 111.4 \\
1986 & 105.4 & 116.9 & 123.1 & 112.3 \\
1987 & 106.8 & 112.8 & 118.9 & 111.0 \\
1988 & 101.5 & 114.5 & 117.7 & 108.8 \\
1989 & 105.2 & 121.0 & 124.3 & 113.9 \\
1990 (census) & 105.2 & 121.4 & 127.0 & 111.3 \\
1992 (0.1\% sample) & 106.7 & 125.7 & 126.7 & 118.8 \\
1995 (1\% sample) & 106.4 & 141.1 & 154.3 & 115.6 \\
2000 (census) & 107.1 & 151.9 & 159.4 & 116.9 \\
\hline
\end{tabular}

Sources: Data covering the period from 1960 to 1989 are taken from $\mathrm{Gu}$ and $\mathrm{Xu}$ (1994) and Gu and Roy (1995), with their calculations having been drawn from the Data Volumes of the National Reproduction and Birth control Sample Surveys, Chapter 3. The 1990 (census results), 1995 (1\% population survey results) and 2000 (census results) data are taken from Yuan and $\mathrm{Tu}$ (2005). The 1992 data is the result of a $0.1 \%$ sample which was taken from the Chinese Population Statistical Yearbook. 
Table 2 Summary Statistics: Sex ratio at birth, by birth order and HBsAg status, by mother's age at first birth $\leq 25$ years

\begin{tabular}{|c|c|c|c|c|c|c|c|}
\hline \multirow{2}{*}{$\begin{array}{l}\text { Birth } \\
\text { Order }\end{array}$} & \multicolumn{2}{|c|}{ Observations } & \multicolumn{2}{|c|}{$\begin{array}{l}\text { HBsAg }(+) \\
\text { Prevalence }\end{array}$} & \multicolumn{3}{|c|}{$\begin{array}{c}\text { Proportion of Male Births } \\
\text { (Sex Ratio, Total Men/ } 100 \text { Women) }\end{array}$} \\
\hline & Total No. & $\%$ & Total No. & $\%$ & HBsAg (-) & HBsAg $(+)$ & Difference \\
\hline First & 721,190 & 50.1 & 122,561 & 17.0 & $\begin{array}{c}0.51440 \\
(105.9)\end{array}$ & $\begin{array}{c}0.51678 \\
(106.9)\end{array}$ & $\begin{array}{c}0.00238 \\
(1.0)\end{array}$ \\
\hline Second & 516,491 & 35.8 & 88,461 & 17.1 & $\begin{array}{c}0.51598 \\
(106.6)\end{array}$ & $\begin{array}{c}0.51745 \\
(107.2)\end{array}$ & $\begin{array}{c}0.00147 \\
(0.6)\end{array}$ \\
\hline $\begin{array}{l}\text { Third (or } \\
\text { subsequent) }\end{array}$ & 203,268 & 14.1 & 35,992 & 17.7 & $\begin{array}{c}0.53151 \\
(113.4) \\
\end{array}$ & $\begin{array}{c}0.53395 \\
(114.6) \\
\end{array}$ & $\begin{array}{c}0.00245 \\
(1.1)\end{array}$ \\
\hline Totals & $1,440,949$ & 100 & 247,104 & 17.1 & $\begin{array}{l}0.51736 \\
(107.2)\end{array}$ & $\begin{array}{l}0.51969 \\
(108.2)\end{array}$ & $\begin{array}{c}0.00233 \\
(1.0)\end{array}$ \\
\hline
\end{tabular}


Table 3: Effect of HBsAg, birth order and their interactions on male probablility: Probit results for mother's age at first birth $<=25$ years

\begin{tabular}{|c|c|c|c|c|c|c|}
\hline \multirow{2}{*}{ variables } & \multicolumn{6}{|c|}{ Probability of Male Birth } \\
\hline & (1) & (2) & (3) & (4) & (5) & (6) \\
\hline \multirow[t]{2}{*}{ Sample Used } & \multirow{2}{*}{\multicolumn{5}{|c|}{ Mother's age at first birth $<=25$ years }} & $\begin{array}{c}\text { Mother's age at } \\
1988<=25\end{array}$ \\
\hline & & & & & & \\
\hline \multirow[t]{3}{*}{$\operatorname{HBsAg}(+)$} & 0.00233 & 0.00223 & 0.00232 & 0.00224 & 0.00270 & 0.00096 \\
\hline & [0.00584] & {$[0.00561]$} & {$[0.00582]$} & {$[0.00563]$} & [0.00677] & {$[0.00242]$} \\
\hline & $(0.00277)^{*}$ & $(0.00277)^{*}$ & $(0.00277)^{*}$ & $(0.00278)^{*}$ & $(0.00393)$ & $(0.01024)$ \\
\hline \multirow[t]{3}{*}{ Second Birth } & & 0.00137 & -0.00167 & -0.00174 & -0.00153 & 0.00859 \\
\hline & & {$[0.00344]$} & {$[-0.00419]$} & {$[-0.00436]$} & {$[-0.00383]$} & {$[0.02156]$} \\
\hline & & $(0.00229)$ & $(0.00277)$ & $(0.00278)$ & $(0.00297)$ & $(0.02687)$ \\
\hline \multirow[t]{3}{*}{ Third(or subsequent) Birth } & & 0.01706 & 0.01081 & 0.01076 & 0.01077 & 0.02747 \\
\hline & & {$[0.04285]$} & {$[0.02713]$} & {$[0.02701]$} & {$[0.02705]$} & {$[0.06903]$} \\
\hline & & $(0.00315)^{* *}$ & $(0.00404)^{* *}$ & $(0.00407)^{* *}$ & $(0.00432)^{* *}$ & $(0.02824)^{*}$ \\
\hline \multirow{3}{*}{$\operatorname{HBsAg}(+) * \operatorname{Second}$ Birth } & & & & & -0.00123 & -0.00181 \\
\hline & & & & & {$[-0.00308]$} & {$[-0.00455]$} \\
\hline & & & & & $(0.00607)$ & $(0.01544)$ \\
\hline \multirow{3}{*}{$\begin{array}{l}\operatorname{HBsAg}(+)^{*} \text { Third } \\
\text { (or subsequent) Birth }\end{array}$} & & & & & -0.00010 & 0.00592 \\
\hline & & & & & {$[-0.00026]$} & {$[0.01485]$} \\
\hline & & & & & $(0.00829)$ & $(0.01866)$ \\
\hline \multicolumn{7}{|l|}{ Other Controls } \\
\hline Age of Mother & No & No & Yes & Yes & Yes & Yes \\
\hline Year of Birth & No & No & Yes & Yes & Yes & Yes \\
\hline Township & No & No & No & Yes & Yes & Yes \\
\hline \multirow[t]{2}{*}{ Constant } & [0.04353] & {$[0.03630]$} & 0.01928 & 0.05867 & {$[0.05848]$} & [0.05387] \\
\hline & $(0.00115)^{* *}$ & $(0.00155)^{* *}$ & $(0.02584)$ & $(0.02770)^{*}$ & $(0.02771)^{*}$ & $(0.10884)$ \\
\hline Observations & 1440949 & 1440949 & 1440949 & 1440949 & 1440949 & 225063 \\
\hline Pseudi R-squred & 0.0000 & 0.0001 & 0.0001 & 0.0004 & 0.0004 & 0.0017 \\
\hline
\end{tabular}

Notes:

a. column (6) uses sample of infants whose mother's age at first birth $<=25$ years in 1988 only.

b. Figures in parentheses are robust standard errors; in brackets are coefficients.

c. * indicates significance at the 5 percent level; ** indicates significance at the 1 percent level 
Table 4: Effect of HBsAg, birth orders, and their interaction on male probability:

Probit results for full sample

\begin{tabular}{|c|c|c|c|c|c|}
\hline \multirow{2}{*}{ Variables } & \multicolumn{5}{|c|}{ Probability of Male Birth } \\
\hline & (1) & (2) & (3) & (4) & (5) \\
\hline \multirow[t]{3}{*}{$\operatorname{HBsAg}(+)$} & 0.00242 & 0.00232 & 0.00255 & 0.0025 & 0.00234 \\
\hline & {$[0.00608]$} & {$[0.00583]$} & {$[0.00639]$} & {$[0.00625]$} & {$[0.00587]$} \\
\hline & $(0.00191)^{* *}$ & $(0.00191)^{* *}$ & $(0.00191)^{* *}$ & $(0.00192)^{* *}$ & $(0.00256)^{*}$ \\
\hline \multirow[t]{3}{*}{ Second Birth } & & 0.00151 & 0.00045 & 0.00051 & 0.00044 \\
\hline & & {$[0.00380]$} & {$[0.00114]$} & {$[0.00129]$} & {$[0.00111]$} \\
\hline & & $(0.00155)^{*}$ & $(0.00164)$ & $(0.00165)$ & $(0.00178)$ \\
\hline \multirow[t]{3}{*}{ Third(or subsequent) Birth } & & 0.01804 & 0.01641 & 0.0166 & 0.01658 \\
\hline & & {$[0.04532]$} & {$[0.04122]$} & [0.04169] & {$[0.04166]$} \\
\hline & & $(0.00241)^{* *}$ & $(0.00254)^{* *}$ & $(0.00256)^{* *}$ & $(0.00279)^{* *}$ \\
\hline \multirow[t]{3}{*}{$\operatorname{HBsAg}(+) *$ Second Birth } & & & & & 0.00044 \\
\hline & & & & & {$[0.00111]$} \\
\hline & & & & & $(0.00419)$ \\
\hline HBsAg $(+) *$ Third & & & & & 0.00006 \\
\hline \multirow[t]{2}{*}{ (or subsequent) Birth } & & & & & {$[0.00016]$} \\
\hline & & & & & $(0.006409)$ \\
\hline \multicolumn{6}{|l|}{ Other Controls } \\
\hline Age of Mother & No & No & Yes & Yes & Yes \\
\hline Year of Birth & No & No & Yes & Yes & Yes \\
\hline Township & No & No & No & Yes & Yes \\
\hline \multirow[t]{2}{*}{ Constant } & 0.04793 & 0.04207 & 0.02155 & 0.06355 & 0.06362 \\
\hline & $(0.00078)^{* *}$ & $(0.00099)^{* *}$ & $(0.02566)$ & $(0.02642)$ & $(0.02643)^{*}$ \\
\hline Observations & 3126002 & 3126002 & 3126002 & 3126002 & 3126002 \\
\hline Pseudi R-squred & 0.0000 & 0.0001 & 0.0002 & 0.0003 & 0.0003 \\
\hline
\end{tabular}

Notes:

a. Figures in parentheses are robust standard errors; in brackets are coefficients.

b. * indicates significance at the 5 percent level; $\quad * *$ indicates significance at the 1 percent level 
Table 5: Effect of HBSAg on male probability, Probit results by birth order

\begin{tabular}{|c|c|c|c|c|c|c|c|c|c|}
\hline & \multicolumn{3}{|c|}{ First Birth } & \multicolumn{3}{|c|}{ Second Birth } & \multicolumn{3}{|c|}{ Third (or subsequent) Birth } \\
\hline & (1) & (2) & (3) & (4) & (5) & (6) & (7) & (8) & (9) \\
\hline Sample Used & $\begin{array}{l}\text { Mother's age at } \\
\text { first birth }<=25\end{array}$ & $\begin{array}{l}\text { Mother's age } \\
\text { at first } \\
\text { birth }<=25 \text { in } \\
1988\end{array}$ & Full sample & $\begin{array}{c}\text { Mother's age } \\
\text { at first } \\
\text { birth }<=25\end{array}$ & $\begin{array}{c}\text { Mother's age at } \\
\text { first birth }<=25 \\
\text { in } 1988\end{array}$ & Full sample & $\begin{array}{c}\text { Mother's age } \\
\text { at first } \\
\text { birth }<=25\end{array}$ & $\begin{array}{c}\text { Mother's age } \\
\text { at first } \\
\text { birth }<=25 \text { in } \\
1988\end{array}$ & Full sample \\
\hline \multirow[t]{3}{*}{$\operatorname{HBsAg}(+)$} & 0.00282 & 0.00131 & 0.00235 & 0.00131 & -0.00124 & 0.00265 & 0.00254 & 0.00592 & 0.00274 \\
\hline & {$[0.00708]$} & {$[0.00329]$} & {$[0.00591]$} & {$[0.00328]$} & {$[-0.00311]$} & {$[0.00664]$} & {$[0.00640]$} & {$[0.01491]$} & {$[0.00690]$} \\
\hline & $(0.00394)$ & $(0.01027)$ & $(0.00256)^{*}$ & $(0.00464)$ & $(0.01162)$ & $(0.00333)^{*}$ & $(0.00732)$ & $(0.01576)$ & $(0.00590)$ \\
\hline \multicolumn{10}{|l|}{ Other Controls } \\
\hline Age of Mother & Yes & Yes & Yes & Yes & Yes & Yes & Yes & Yes & Yes \\
\hline Year of Birth & Yes & Yes & Yes & Yes & Yes & Yes & Yes & Yes & Yes \\
\hline Township & Yes & Yes & Yes & Yes & Yes & Yes & Yes & Yes & Yes \\
\hline \multirow[t]{2}{*}{ Constant } & 0.06543 & 0.05488 & 0.06844 & 0.07941 & 0.47318 & 0.07353 & 0.34321 & 0.68195 & 0.1778 \\
\hline & $(0.02973)^{*}$ & $(0.11187)$ & $(0.02745)^{*}$ & $(0.12871)$ & $(0.24454)$ & $(0.12650)$ & $(0.41461)$ & $(0.65586)$ & $(0.40519)$ \\
\hline Observations & 721190 & 100759 & 1767657 & 516491 & 80580 & 1037902 & 203268 & 43724 & 320443 \\
\hline Pesudo R-squared & 0.0004 & 0.0027 & 0.0003 & 0.0006 & 0.0038 & 0.0004 & 0.0017 & 0.0069 & 0.0014 \\
\hline
\end{tabular}


Table 6: Effect of HBsAg, sex composition of the first two children and their interaction on male probability: Probit results from the third birth

\begin{tabular}{|c|c|c|c|c|c|c|}
\hline & (1) & (2) & (3) & (4) & (5) & (6) \\
\hline Sample Used & & Mother's age at fi & $\mathrm{t}$ birth $<=25$ years & & $\begin{array}{c}\text { Mother's age at } \\
\text { first birth }<=25 \\
\text { years in } 1988 \\
\text { only }\end{array}$ & Full sample \\
\hline \multirow[t]{3}{*}{ HBsAg $(+)$} & -0.00008 & 0.00006 & 0.00018 & -0.00198 & -0.00245 & -0.00029 \\
\hline & {$[-0.00021]$} & {$[0.00016]$} & [0.00044] & {$[-0.00496]$} & {$[-0.00617]$} & {$[-0.00074]$} \\
\hline & $(0.00787)$ & $(0.00787)$ & $(0.00790)$ & $(0.00957)$ & $(0.02145)$ & $(0.00771)$ \\
\hline First two children & & 0.02473 & 0.02450 & 0.02332 & 0.02220 & 0.02147 \\
\hline \multirow[t]{2}{*}{ are both girls } & & {$[0.06222]$} & {$[0.06163]$} & {$[0.05866]$} & {$[0.05589]$} & {$[0.05407]$} \\
\hline & & $(0.00642)^{* *}$ & $(0.00644)^{* *}$ & $(0.00709)^{* *}$ & $(0.01568)^{* *}$ & $(0.00552)^{* *}$ \\
\hline HBsAG(+)*First two & & & & 0.00677 & 0.00376 & 0.00301 \\
\hline \multirow[t]{2}{*}{ children are both girls } & & & & {$[0.01702]$} & {$[0.00947]$} & {$[0.00757]$} \\
\hline & & & & $(0.01695)$ & $(0.03703)$ & $(0.01336)$ \\
\hline \multicolumn{7}{|l|}{ Other Controls } \\
\hline Age of Mother & No & No & Yes & Yes & Yes & Yes \\
\hline Year of Birth & No & No & Yes & Yes & Yes & Yes \\
\hline Township & No & No & Yes & Yes & Yes & Yes \\
\hline \multirow[t]{2}{*}{ Constant } & 0.07411 & 0.05401 & 0.32141 & 0.32197 & 0.51314 & 0.17083 \\
\hline & $(0.00330)^{* *}$ & $(0.00390)^{* *}$ & $(0.41995)$ & $(0.41983)$ & $(0.71008)$ & $(0.40914)$ \\
\hline Observations & 175005 & 175005 & 175005 & 175005 & 35557 & 281357 \\
\hline Pseudo R-squared & 0.0000 & 0.0004 & 0.0022 & 0.0022 & 0.0084 & 0.0018 \\
\hline
\end{tabular}

Notes:

a. Figures in parentheses are robust standard errors; in brackets are coefficients.

b. * indicates significance at the 5 percent level; $* *$ indicates significance at the 1 percent level 


\section{APPENDIX:}

Table A1 Summary Statistics: Sex ratio at birth, by birth order and HBsAg status: the three million sample

\begin{tabular}{|c|c|c|c|c|c|c|c|}
\hline \multirow{2}{*}{$\begin{array}{l}\text { Birth } \\
\text { Order }\end{array}$} & \multicolumn{2}{|c|}{ Observations } & \multicolumn{2}{|c|}{$\begin{array}{l}\text { HBsAg }(+) \\
\text { Prevalence }\end{array}$} & \multicolumn{3}{|c|}{$\begin{array}{c}\text { Proportion of Male Births } \\
\text { (Sex Ratio, Total Men/ } 100 \text { Women) }\end{array}$} \\
\hline & Total No. & $\%$ & Total No. & $\%$ & HBsAg (-) & $\operatorname{HBsAg}(+)$ & Difference \\
\hline First & $1,767,657$ & 56.5 & 288,461 & 16.3 & $\begin{array}{c}0.51680 \\
(107.0)\end{array}$ & $\begin{array}{c}0.51900 \\
(107.9)\end{array}$ & $\begin{array}{c}0.00220 \\
(0.9)\end{array}$ \\
\hline Second & $1,037,902$ & 33.2 & 170,508 & 16.4 & $\begin{array}{c}0.51825 \\
(107.6)\end{array}$ & $\begin{array}{c}0.52081 \\
(108.7)\end{array}$ & $\begin{array}{c}0.00256 \\
(1.1)\end{array}$ \\
\hline $\begin{array}{l}\text { Third (or } \\
\text { subsequent) }\end{array}$ & 320,443 & 10.3 & 55,073 & 17.2 & $\begin{array}{c}0.53484 \\
(115.0)\end{array}$ & $\begin{array}{c}0.53703 \\
(116.0)\end{array}$ & $\begin{array}{c}0.00219 \\
(1.0)\end{array}$ \\
\hline Totals & $3,126,002$ & 100.0 & 514,042 & 16.4 & $\begin{array}{l}0.51911 \\
(107.9)\end{array}$ & $\begin{array}{c}0.52154 \\
(109.0)\end{array}$ & $\begin{array}{c}0.00243 \\
(1.1)\end{array}$ \\
\hline
\end{tabular}


Table A2: Sex Ratio at Birth by Birth Order in Taiwan and South Korea: 1980-2000

\begin{tabular}{lllll|llll}
\multicolumn{5}{c}{ Taiwan } & \multicolumn{3}{c}{ South } & Korea \\
\hline & Total & First & 2nd & 3rd & Total & First & 2nd & 3rd \\
& & Child & Child & Child + & & Child & Child & Child+ \\
\hline 1980 & 106.5 & & & & 103.9 & 105.7 & 104.2 & 101.5 \\
1981 & 107.1 & & & & 107.2 & 106.3 & 106.7 & 109.4 \\
1982 & 106.9 & & & & 106.8 & 105.4 & 106.0 & 110.9 \\
1983 & 107.1 & & & & 107.4 & 105.8 & 106.2 & 114.7 \\
1984 & 107.4 & & & & 108.3 & 106.1 & 107.2 & 120.7 \\
1985 & 106.7 & & & & 109.4 & 106.0 & 107.8 & 134.3 \\
1986 & 107.3 & & & & 111.7 & 107.3 & 111.2 & 141.5 \\
1987 & 108.4 & 107.2 & 108.2 & 110.8 & 108.8 & 104.7 & 109.1 & 137.9 \\
1988 & 108.2 & 107.3 & 106.9 & 112.0 & 113.3 & 107.2 & 113.2 & 168.3 \\
1989 & 108.6 & 107.0 & 106.9 & 114.8 & 111.7 & 104.1 & 112.4 & 185.0 \\
1990 & 110.3 & 106.8 & 108.7 & 120.8 & 116.5 & 108.5 & 117.0 & 192.7 \\
1991 & 110.4 & 107.4 & 108.5 & 120.3 & 112.4 & 105.7 & 112.4 & 182.1 \\
1992 & 109.9 & 108.0 & 107.5 & 118.5 & 113.6 & 106.2 & 112.4 & 194.4 \\
1993 & 108.1 & 107.1 & 106.7 & 112.9 & 115.3 & 106.4 & 114.7 & 206.6 \\
1994 & 108.9 & 107.8 & 107.3 & 114.1 & 115.2 & 105.9 & 114.1 & 205.1 \\
1995 & 107.9 & 107.0 & 105.5 & 114.6 & 113.2 & 105.8 & 111.7 & 180.2 \\
1996 & 108.8 & 107.9 & 107.0 & 114.0 & 111.6 & 105.3 & 109.8 & 166.2 \\
1997 & 108.9 & 107.7 & 106.9 & 115.6 & 108.2 & 105.1 & 106.3 & 135.5 \\
1998 & 108.7 & 107.0 & 106.8 & 116.7 & 110.1 & 105.9 & 108.0 & 145.6 \\
1999 & 109.5 & 106.9 & 107.8 & 121.0 & 109.6 & 105.6 & 107.6 & 143.1 \\
2000 & 109.4 & 106.9 & 107.7 & 121.2 & 110.1 & 106.2 & 107.4 & 143.9 \\
\hline & & & & & & & &
\end{tabular}

Note: Source of Data: Taiwan National Statistical Office and South Korea National Statistical Office. 
Table A3: Effect of HBsAg, birth order and their interactions on male probablility: OLS results for mother's age at first birth $<=25$ years

\begin{tabular}{|c|c|c|c|c|c|c|}
\hline & (1) & (2) & (3) & (4) & (5) & (6) \\
\hline Sample Used & \multicolumn{5}{|c|}{ Mother's age at first birth $<=25$ years } & $\begin{array}{c}\text { Mother's age at } \\
\qquad 1988<=25\end{array}$ \\
\hline \multirow[t]{2}{*}{$\operatorname{HBsAg}(+)$} & 0.00233 & 0.00223 & 0.00232 & 0.00224 & 0.00270 & 0.00097 \\
\hline & {$[0.00110]^{*}$} & {$[0.00110]^{*}$} & {$[0.00110]^{*}$} & {$[0.00111]^{*}$} & {$[0.00157]$} & {$[0.00408]$} \\
\hline \multirow[t]{2}{*}{ Second Birth } & & 0.00137 & -0.00167 & -0.00174 & -0.00153 & 0.00856 \\
\hline & & {$[0.00091]$} & {$[0.00111]$} & {$[0.00111]$} & {$[0.00118]$} & {$[0.01069]$} \\
\hline \multirow[t]{2}{*}{ Third(or subsequent) Birth } & & 0.01706 & 0.0108 & 0.01075 & 0.01076 & 0.02742 \\
\hline & & {$[0.00125]^{* *}$} & {$[0.00161]^{* *}$} & {$[0.00162]^{* *}$} & {$[0.00172]^{* *}$} & {$[0.01123]^{*}$} \\
\hline \multirow[t]{2}{*}{$\mathrm{HBsAg}(+) *$ Second Birth } & & & & & -0.00123 & -0.00183 \\
\hline & & & & & {$[0.00242]$} & {$[0.00615]$} \\
\hline HBsAg $(+) *$ Third & & & & & -0.00010 & 0.00587 \\
\hline (or subsequent) Birth & & & & & {$[0.00330]$} & {$[0.00741]$} \\
\hline \multicolumn{7}{|l|}{ Other Controls } \\
\hline Age of Mother & No & No & Yes & Yes & Yes & Yes \\
\hline Year of Birth & No & No & Yes & Yes & Yes & Yes \\
\hline Township & No & No & No & Yes & Yes & Yes \\
\hline \multirow[t]{2}{*}{ Constant } & 0.51736 & 0.51448 & 0.50769 & 0.52337 & 0.5233 & 0.52146 \\
\hline & {$[0.00046]^{* *}$} & {$[0.00062]^{* *}$} & {$[0.01030]^{* *}$} & {$[0.01104]^{* *}$} & {$[0.01104]^{* *}$} & {$[0.04333]^{* *}$} \\
\hline Observations & 1440949 & 1440949 & 1440949 & 1440949 & 1440949 & 225063 \\
\hline R-squared & 0.0000 & 0.0001 & 0.0002 & 0.0005 & 0.0005 & 0.0024 \\
\hline
\end{tabular}

Notes:

a. Figures in parentheses are robust standard errors

b. * indicates significance at the 5 percent level; ** indicates significance at the 1 percent level 
Table A4: Effect of HBsAg, birth orders, and their interaction on male probability:

OLS results for full sample

\begin{tabular}{lccccc}
\hline & $(1)$ & $(2)$ & $(3)$ & $(4)$ & $(5)$ \\
\hline HBsAg(+) & 0.00242 & 0.00232 & 0.00255 & 0.00249 & 0.00234 \\
& {$[0.00076]^{* *}$} & {$[0.00076]^{* *}$} & {$[0.00076]^{* *}$} & {$[0.00076]^{* *}$} & {$[0.00102]^{*}$} \\
Second Birth & & 0.00151 & 0.00046 & 0.00051 & 0.00044 \\
& & {$[0.00062]^{*}$} & {$[0.00065]$} & {$[0.00066]$} & {$[0.00071]$} \\
Third(or subsequent) Birth & & 0.01804 & 0.0164 & 0.01659 & 0.01658 \\
& & {$[0.00096]^{* *}$} & {$[0.00101]^{* *}$} & {$[0.00102]^{* *}$} & {$[0.00111]^{* *}$} \\
HBsAg(+)*Second Birth & & & & & 0.00044 \\
& & & & & {$[0.00167]$} \\
HBsAg(+)*Third & & & & & 0.00006 \\
(or subsequent) Birth & & & & & \\
Other Controls & & & & & \\
Age of Mother & No & No & Yes & Yes & Yes \\
Year of Birth & No & No & Yes & Yes & Yes \\
Township & No & No & No & Yes & Yes \\
Constant & 0.51911 & 0.51678 & 0.50860 & 0.52531 & 0.52534 \\
& {$[0.00031]^{* *}$} & {$[0.00040]^{* *}$} & {$[0.01023]^{* *}$} & {$[0.01053]^{* *}$} & {$[0.01053]^{* *}$} \\
\hline Observations & 3126002 & 3126002 & 3126002 & 3126002 & 3126002 \\
R-squared & 0.0000 & 0.0001 & 0.0002 & 0.0004 & 0.0004 \\
\hline
\end{tabular}

Notes:

a. Figures in parentheses are robust standard errors

b. * indicates significance at the 5 percent level; $* *$ indicates significance at the 1 percent level 
Table A5: Effect of HBSAg on male probability: OLS results by birth order

\begin{tabular}{|c|c|c|c|c|c|c|c|c|c|}
\hline \multirow[b]{3}{*}{ Sample Used } & \multicolumn{3}{|c|}{ First Birth } & \multicolumn{3}{|c|}{ Second Birth } & \multicolumn{3}{|c|}{ Third (or subsequent) Birth } \\
\hline & (1) & (2) & (3) & (4) & (5) & (6) & (7) & (8) & (9) \\
\hline & $\begin{array}{l}\text { Mother's age at } \\
\text { first birth }<=25\end{array}$ & $\begin{array}{c}\text { Mother's age at } \\
\text { first birth }<=25 \text { in } \\
1988\end{array}$ & Full sample & $\begin{array}{l}\text { Mother's age at } \\
\text { first birth }<=25\end{array}$ & $\begin{array}{c}\text { Mother's age at } \\
\text { first birth }<=25 \text { in } \\
1988\end{array}$ & Full sample & $\begin{array}{l}\text { Mother's age at } \\
\text { first birth }<=25\end{array}$ & $\begin{array}{c}\text { Mother's age at } \\
\text { first birth }<=25 \text { in } \\
1988\end{array}$ & Full sample \\
\hline \multirow[t]{2}{*}{$\operatorname{HBsAg}(+)$} & 0.00282 & 0.00130 & 0.00235 & 0.00131 & -0.00123 & 0.00264 & 0.00254 & 0.00584 & 0.00273 \\
\hline & {$[0.00157]$} & {$[0.00409]$} & {$[0.00102]^{*}$} & {$[0.00185]$} & {$[0.00462]$} & {$[0.00133]^{*}$} & {$[0.00291]$} & {$[0.00623]$} & {$[0.00234]$} \\
\hline \multicolumn{10}{|l|}{ Other Controls } \\
\hline Age of Mother & Yes & Yes & Yes & Yes & Yes & Yes & Yes & Yes & Yes \\
\hline Year of Birth & Yes & Yes & Yes & Yes & Yes & Yes & Yes & Yes & Yes \\
\hline Township & Yes & Yes & Yes & Yes & Yes & Yes & Yes & Yes & Yes \\
\hline \multirow[t]{2}{*}{ Constant } & 0.52607 & 0.52195 & 0.52726 & 0.53166 & 1.02725 & 0.52929 & 0.63491 & 0.74152 & 0.56929 \\
\hline & {$[0.01184]^{* *}$} & {$[0.04463]^{* *}$} & {$[0.01094]^{* *}$} & {$[0.05126]^{* *}$} & {$[0.03800]^{* *}$} & {$[0.05040]^{* *}$} & {$[0.15954]^{* *}$} & {$[0.20231]^{* *}$} & {$[0.15587]^{* *}$} \\
\hline Observations & 721190 & 100759 & 1767657 & 516491 & 80580 & 1037902 & 203268 & 43724 & 320443 \\
\hline Pesudo R-squared & 0.0006 & 0.0039 & 0.0004 & 0.0008 & 0.0053 & 0.0005 & 0.0024 & 0.0098 & 0.0020 \\
\hline
\end{tabular}

Notes:

a. Figures in parentheses are robust standard errors

b. * indicates significance at the 5 percent level; ** indicates significance at the 1 percent level 
Table A6: Effect of HBsAg, sex composition of the first two children and their interaction on male probability: OLS results from the third birth

(1)

(2)

(3)

(4)

(5)

(6)

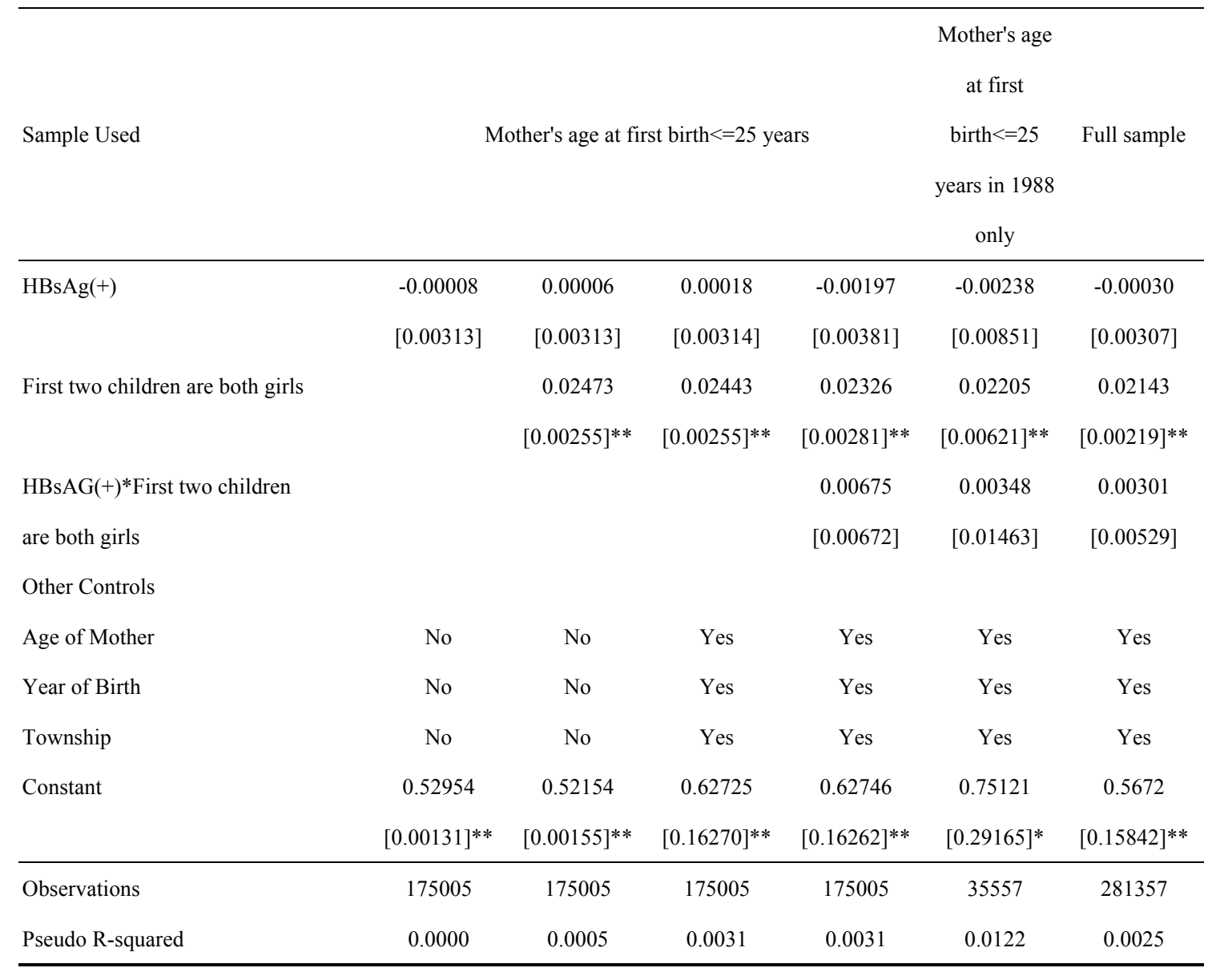

Notes:

a. Figures in parentheses are robust standard errors

b. * indicates significance at the 5 percent level; ** indicates significance at the 1 percent level 